\title{
Kinetic Approach to the Mechanism of Oxidation of L-Ascorbic Acid by Periodate Ion in Acidic Medium
}

\author{
Babatunde O.A \\ Department of Chemistry, Nigerian Defence Academy, Kaduna \\ E-mail: mails4abiodun@yahoo.com \\ Nwakama O.N \\ Department of Chemistry, Nigerian Defence Academy, Kaduna
}

Received: October 30, 2012 Accepted: November 18, 2012

doi:10.5296/jbls.v4i2.3349 URL: http://dx.doi.org/10.5296/jbls.v4i2.3349

\begin{abstract}
The aim of this study is to investigate the mechanistic pathway of the oxidation of L-ascorbic acid by periodate ions in acidic medium reaction. The oxidation of $\mathrm{L}$-ascorbic acid $\left(\mathrm{H}_{2} \mathrm{~A}\right)$ by periodate ions in acidic medium has been investigated under pseudo-first order conditions at 27 $\pm 0^{\circ} \mathrm{C},\left[\mathrm{H}^{+}\right]=1.0 \times 10^{-3} \mathrm{~mol} \mathrm{dm}^{-3}, \mathrm{I}=1.0 \mathrm{~mol} \mathrm{dm}^{-3}(\mathrm{NaCl})$ and $\lambda_{\max } 430 \mathrm{~nm}$. The stoichiometry of the reaction was observed to be 2:7 in terms of mole ratio of periodate ions and ascorbic acid consumed. The reaction is first order in both reactants and shows dependence on acid concentration.
\end{abstract}

The proposed rate law is

$-\frac{2}{7} \frac{\mathrm{d}\left[\mathrm{IO}_{4}^{-}\right]}{\mathrm{dt}}=\left(\mathrm{a}+\mathrm{b}\left[\mathrm{H}^{+}\right]\right)\left[\mathrm{H}_{2} \mathrm{~A}\right]\left[\mathrm{IO}_{4}^{-}\right]$

With $\mathrm{a}=7.15 \times 10^{-2} \cdot \mathrm{dm}^{3} \mathrm{~mol}^{-1} \mathrm{~s}^{-1}$ (intercept) and $\mathrm{b}=5.53 \times 10^{-1} \mathrm{~mol} \mathrm{dm}{ }^{6} \mathrm{~mol}^{-2} \mathrm{~s}^{-1}$ (slope). The rate of reaction increased with increase in ionic strength. There is no evidence for the formation of an intermediate complex of significant stability and free radicals are probably not present in the reactions. This is supported by the result of the Michealis-Menten's plot. A plausible mechanism consistent with the outersphere mechanism is proposed.

Keywords: Ascorbic acid, Periodate ions. 


\section{Introduction}

Ascorbic acid also known as vitamin $\mathrm{C}$ is an organic acid with anti-oxidant properties that plays a vital role in protecting the body from infection and disease. It is of great importance to the human body to the extent that its deficiency leads to various diseases including scurvy and found in appreciable concentration in the juice of many fruits, particularly those of the citrus family. (Meridhamet al., 2006).Ascorbic acid can be partially or completely destroyed by over-cooking or long period of storage as it is sensitive to heat, light and oxygen (Akhtar and Haim, 1988)Reactive oxygen species oxidize it to monohydroascorbic acid (HA ) a radical which was fond to be a strong acid and dehydroascorbic acid. The reactive oxygen is reduced to water, while the oxidized forms of ascorbate are relatively stable and unreactive and do not cause cellular damage (Ghosh and Goud, 1989; Mushroom et al, 1974; Iyun et al., 2005;Cruetz, 1981; Benson,1968; Bamford and Tipper 1967; Lawrence and Ellis, 1972). It is therefore widely used as a reducing agent in chemical and biological systems where it acts as an electron donor for important enzymes (Birck and Parket, 1974; Levine et al., 2000). As such the oxidation of ascorbic acid is a very important redox reaction.A literature survey shows that redox reaction of ascorbic acid with various inorganic and organic compounds produces various forms of products depending on the $\mathrm{P}^{\mathrm{H}}$ of reaction medium (Ukoha and Iyun 2000;.Khan, 2001; Hamza et al, 2012). In view of these various reactions of ascorbic acid, it is important that research should be done to ascertain its redox reactions in biological systems, ,.pharmaceutical, and food industries.

Choice of periodate ion as the reductant derives from our desire to gain in depth knowledge of the reactions of oxyhalogen anions and the various complexities that attend them. It is an important reductant in electron transfer reactions and has been shown to exist in different species as periodic acid or iodic acid $\mathrm{HIO}_{4}, \mathrm{H}_{5} \mathrm{IO}_{6}, \mathrm{H}_{4} \mathrm{IO}_{6}{ }^{2-}, \mathrm{H}_{3} \mathrm{IO}_{6}{ }^{2-}$ and $\mathrm{IO}_{4}($ Babatunde, 2 009). Periodate ion has the ability to cleave carbon-carbon bonds when both carbon atoms bear an oxygen atom, either is in the form of a hydroxyl or a carbonyl group. This property is often utilized in molecular biochemistry for the purpose of modifying saccharide rings. .

Little is known about the kinetics and mechanism of ascorbic acid and periodate reactions. Therefore, this present study aimed at gaining insight into the redox activities of Ascorbic Acid and Periodate ions for effective use of both the reductant and the oxidant by providing relevant data.

\section{Materials and Methods}

\subsection{Materials}

All preparations were made with distilled water and all chemicals were of analytical grade. L-Ascorbic acid (Fischer) was used without further purification. Potassium periodate (BDH) was also used as supplied. Hydrochloric acid (BDH) was used to investigate the effect of hydrogen ion concentrations on the rate of reactions while sodium chloride (BDH) was employed in maintaining the ionic strength constant at $1.0 \mathrm{~mol} \mathrm{dm}^{-3}$. The rate of reaction was monitored on a Corning Colorimeter 252 model. The materials were obtained in 2010 and the total duration for the completion of the research was five months. 


\section{Macrothink}

\subsection{Stoichiometric Studies/Product Analysis}

The stoichiometry of the reaction was determined by spectrophotometric titration at $\lambda_{\max }$ 430nm using mole ratio method (Iyun et al.,1995; Swapan et al., 1995). Solutions containing known concentrations of $\mathrm{IO}_{4}^{-}\left(1 \times 10^{-3} \mathrm{~mol} \mathrm{dm}{ }^{3}\right)$ and varying concentrations of $\mathrm{H}_{2} \mathrm{~A}$ were reacted at $\left[\mathrm{H}^{+}\right]=1 \times 10^{-3} \mathrm{~mol} \mathrm{dm}{ }^{-3}$ and $\mathrm{I}=1.0 \mathrm{~mol} \mathrm{dm}^{-3}(\mathrm{NaCl})$. The absorbances were measured at wavelength of $430 \mathrm{~nm}$ after the completion of the reaction as indicated by steady absorbance value over a period of two days.(Table 1) A plot of absorbance versus $\mathrm{H}_{2} \mathrm{~A} / \mathrm{IO}_{4}{ }^{-}$was drawn (Figure 1), from which the stoichiometry was evaluated.

Table 1. Data for Determination of the equivalent point.

\begin{tabular}{|l|l|l|}
\hline Volume of Ascorbic Acid Added $\left(\mathrm{cm}^{3}\right)$ & Concentration of Ascorbic Acid $\left(\mathrm{moldm}^{3}\right)$ & Absorbance at 430nm \\
\hline 0.0 & 0.000 & 0.000 \\
\hline 0.5 & $0.5 \times 10^{-3}$ & 0.001 \\
\hline 1.0 & $1.0 \times 10^{-3}$ & 0.003 \\
\hline 1.5 & $1.5 \times 10^{-3}$ & 0.005 \\
\hline 2.0 & $2.0 \times 10^{-3}$ & 0.007 \\
\hline 2.5 & $2.5 \times 10^{-3}$ & 0.009 \\
\hline 3.0 & $3.0 \times 10^{-3}$ & 0.011 \\
\hline 3.5 & $3.5 \times 10^{-3}$ & 0.013 \\
\hline 4.0 & $4.0 \times 10^{-3}$ & 0.013 \\
\hline 4.5 & $4.5 \times 10^{-3}$ & 0.013 \\
\hline 5.0 & $5.0 \times 10^{-3}$ & 0.013 \\
\hline
\end{tabular}

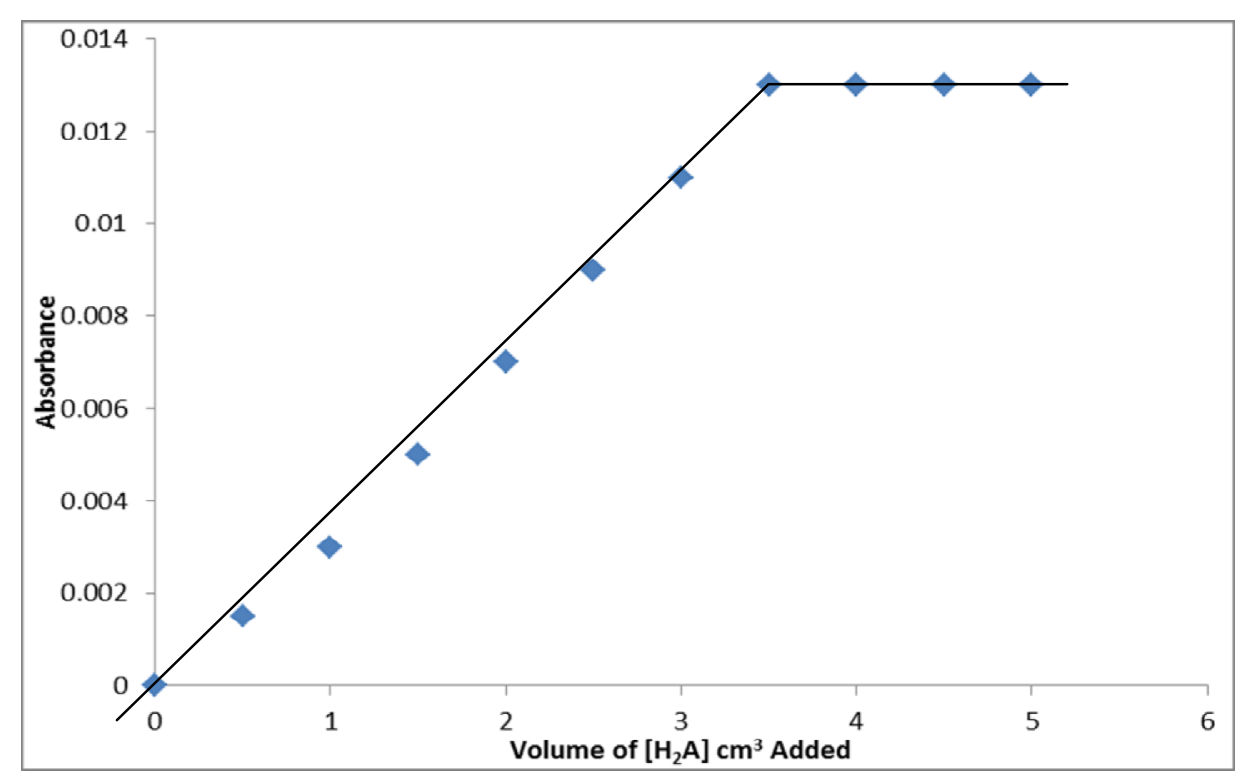

Figure 1. Graph Absorbance against Volume of $\left[\mathrm{H}_{2} \mathrm{~A}\right]$ for determination of equivalent point at $430 \mathrm{~nm}$

The oxidation products were repeatedly analysed by treating with starch solution after the reaction has been completed.

\subsection{Kinetic Studies}




\section{Macrothink}

The preliminary runs of the reactions showed that the kinetics can readily be studied by a conventional method hence the use of a Colorimeter Model 252 Spectrophotometer was employed.

The rate of reaction was monitored by observing the decrease in absorbance of the reaction mixture at maximum wavelength of 430nm using Corning Colorimeter 252. All measurements were made under pseudo-first order conditions with $\left[\mathrm{H}_{2} \mathrm{~A}\right]$ in more than 50 fold excess over $\left[\mathrm{IO}_{4}{ }^{-}\right]$at $30 \pm 1^{\circ} \mathrm{C},\left[\mathrm{H}^{+}\right]=1 \times 10^{-3} \mathrm{~mol} \mathrm{dm}^{-3}$ and $\mathrm{I}=1.0 \mathrm{~mol} \mathrm{dm}{ }^{-3}(\mathrm{NaCl})$. The pseudo first order rate constant $\left(\mathrm{k}_{\mathrm{o}}\right)$ was obtained from logarithmic plots of absorbance difference against time. (Table 2)

Table 2. Pseudo - first order and second- order rate constant for the reaction of Ascorbic acid and periodate ion. $\left[\mathrm{H}_{2} \mathrm{~A}\right]=1 \times 10^{-3} \mathrm{~mol} \mathrm{dm}^{-3}, \mathrm{~T}=27.5 \pm 0.5^{\circ} \mathrm{C},\left[\mathrm{IO}_{4}{ }^{-}\right]=1 \times 10^{-3} \mathrm{~mol} \mathrm{dm}^{-3}$,

$\lambda_{\max }=430 \mathrm{~nm}$

\begin{tabular}{|l|l|l|l|l|}
\hline $10^{2}\left[\mathrm{H}_{2} \mathrm{~A}\right] \mathrm{mol} \mathrm{dm}^{-3}$ & $\mathrm{I}(\mathrm{NaCl}) \mathrm{mol} \mathrm{dm}^{-3}$ & $10^{3}\left[\mathrm{H}^{+}\right] \mathrm{mol} \mathrm{dm}^{-3}$ & $10^{2} \mathrm{k}_{\mathrm{o}} \mathrm{s}^{-1}$ & $10^{1} \mathrm{k}_{2} \mathrm{dm}^{3} \mathrm{~mol}^{-1} \mathrm{~s}^{-1}$ \\
\hline 10 & 1.0 & 1.0 & 7.1 & 7.16 \\
12 & 1.0 & 1.0 & 8.7 & 7.25 \\
14 & 1.0 & 1.0 & 9.9 & 7.17 \\
16 & 1.0 & 1.0 & 11.5 & 7.19 \\
18 & 1.0 & 1.0 & 12.8 & 7.17 \\
20 & 1.0 & 1.0 & 14.3 & 7.15 \\
22 & 1.0 & 1.0 & 15.8 & 7.18 \\
24 & 1.0 & 1.0 & 17.2 & 7.17 \\
26 & 1.0 & 1.0 & 18.7 & 7.19 \\
28 & 1.0 & 1.0 & 20.1 & 7.18 \\
30 & 1.0 & 1.0 & 21.5 & 7.17 \\
\hline 20 & 1.0 & 0.5 & 14.30 & 7.15 \\
20 & 1.0 & 1.0 & 14.40 & 7.20 \\
20 & 1.0 & 5.0 & 14.78 & 7.39 \\
20 & 1.0 & 10.0 & 15.26 & 7.63 \\
20 & 1.0 & 15.0 & 15.72 & 7.86 \\
20 & 1.0 & 20.0 & 16.50 & 8.25 \\
\hline 20 & 0.4 & 1.0 & 6.30 & 3.15 \\
20 & 0.8 & 1.0 & 11.04 & 5.32 \\
20 & 0.8 & 1.0 & 14.36 & 7.18 \\
20 & 1.0 & 1.0 & 18.10 & 9.05 \\
\hline
\end{tabular}

\section{Results and Discussion}

\subsection{Stoichiometry and Product Analysis}

The result of the spectrophotometric titration suggests $2: 7$ stoichiometry. The overall reaction is given by equation 1.

$2 \mathrm{IO}_{4}^{-}+7 \mathrm{H}_{2} \mathrm{~A}+2 \mathrm{H}^{+} \longrightarrow 7 \mathrm{~A}+8 \mathrm{H}_{2} \mathrm{O}+\mathrm{I}_{2}$

$\mathrm{A}=$ dehydroascorbic acid. 
Various types of stoichiometries have been reported for the redox reaction of $\mathrm{H}_{2} \mathrm{~A}$.

Hamza et al 2012 reported a mole ratio of 1:1 for oxidation of toluidine blue by ascorbic acid while a mole ratio of 2:5 for oxidation of ascorbic acid by permanganate ion in acidic medium. Babatunde, 2008 and Iyun et al, 2005 reported 2:3 mole ratio the reduction of di -u-oxotetrakis(1,10-phenanthroline)-dimanganese(III,IV) perchlorate by L-ascorbic acid in aqueous acid solution.

Starch solution was added to partially oxidized reaction mixture of ascorbic acid and periodate ion, a blue black solution was obtained confirming the presence of iodine in the reaction medium.

\subsection{Kinetics}

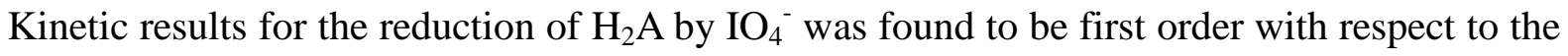
concentration of $\mathrm{IO}_{4}{ }^{-}$as evidenced in the linearity of the pseudo-first order plot of $\log \left(\mathrm{A}_{t^{-}} \mathrm{A} \infty\right)$ versus time where $A_{t}$ and $A \infty$ are the absorbances at time $t$ and at the end of the reaction. The linearity was about $85 \%$ suggesting that there was no product inhibition. Plot of $\log \mathrm{k}_{\mathrm{o}}$ (where $\mathrm{k}_{\mathrm{o}}$ is the pseudo first order rate constant) versus $\log \left[\mathrm{H}_{2} \mathrm{~A}\right]$ was linear with a slope of 0.96 which is approximately one. (Figure 2) This suggests that the reaction is first order in $\left[\mathrm{H}_{2} \mathrm{~A}\right]$. The consistency of the value of $\mathrm{k}_{2}$ - obtained as $k_{o} /\left[\mathrm{H}_{2} \mathrm{~A}\right]$ - suggests that the reaction follows an overall order of second- order (Table 2). Therefore the experimental rate law can be described by equation. 2

$\left.-\frac{2}{7} \frac{\mathrm{d}}{\mathrm{dt}}=\mathrm{IO}_{4}^{-}\right]=\mathrm{k}_{2}\left[\mathrm{H}_{2} \mathrm{~A}\right]\left[\mathrm{IO}_{4}^{-}\right]$

Where $\mathrm{k}_{2}=(7.18 \pm 0.01) \times 10^{-1} \mathrm{dm}^{3} \mathrm{~mol}^{-1} \mathrm{~s}^{-1}$

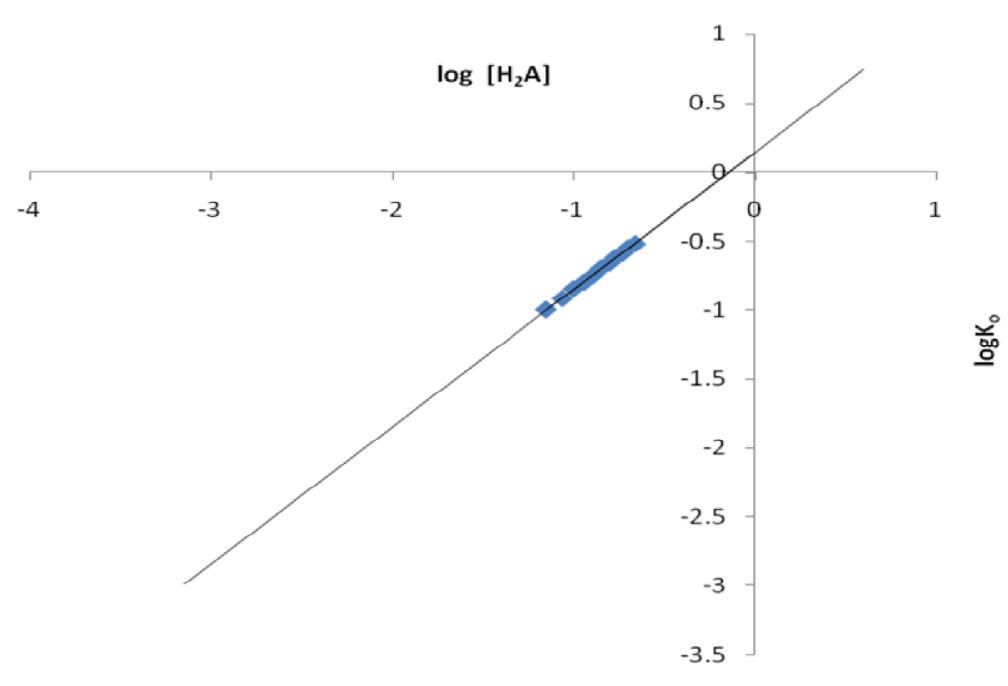

Figure 2. Graph of $\log \mathrm{k}_{\mathrm{o}}$ against $\log \left[\mathrm{H}_{2} \mathrm{~A}\right]$

\subsection{Acid Dependence}




\section{Macrothink}

The oxidation reaction was also found to be acid-dependent within the range of $0.4 \leq\left[\mathrm{H}^{+}\right] \leq 2.0$ mol dm${ }^{-3}$ (Table 1) at $\left[\mathrm{H}_{2} \mathrm{~A}\right]=20 \times 10^{-2} \mathrm{~mol} \mathrm{dm}^{-3},\left[\mathrm{IO}_{4}^{-}\right]=1 \times 10^{-3} \mathrm{~mol} \mathrm{dm}^{-3}, \mathrm{I}=1 \times 10^{-3} \mathrm{~mol} \mathrm{dm}^{-3}$ $(\mathrm{NaCl})$ and $\mathrm{T}=29 \pm 1^{\circ} \mathrm{C}$ was investigated. Plot of $\mathrm{k}_{\mathrm{H}}$ (acid dependent rate constant) vs $\left[\mathrm{H}^{+}\right]$was linear with positive intercept (Figure 3). This effect also indicated two pathways. One that is acid dependent and the other was independent of acid. This implies that both the protonated and deprotonated species are reactive during the reaction (Hassan and Ahmed,1995). Therefore the overall rate of reaction within the range investigated can be expressed as a function of $\left[\mathrm{H}^{+}\right]$ as

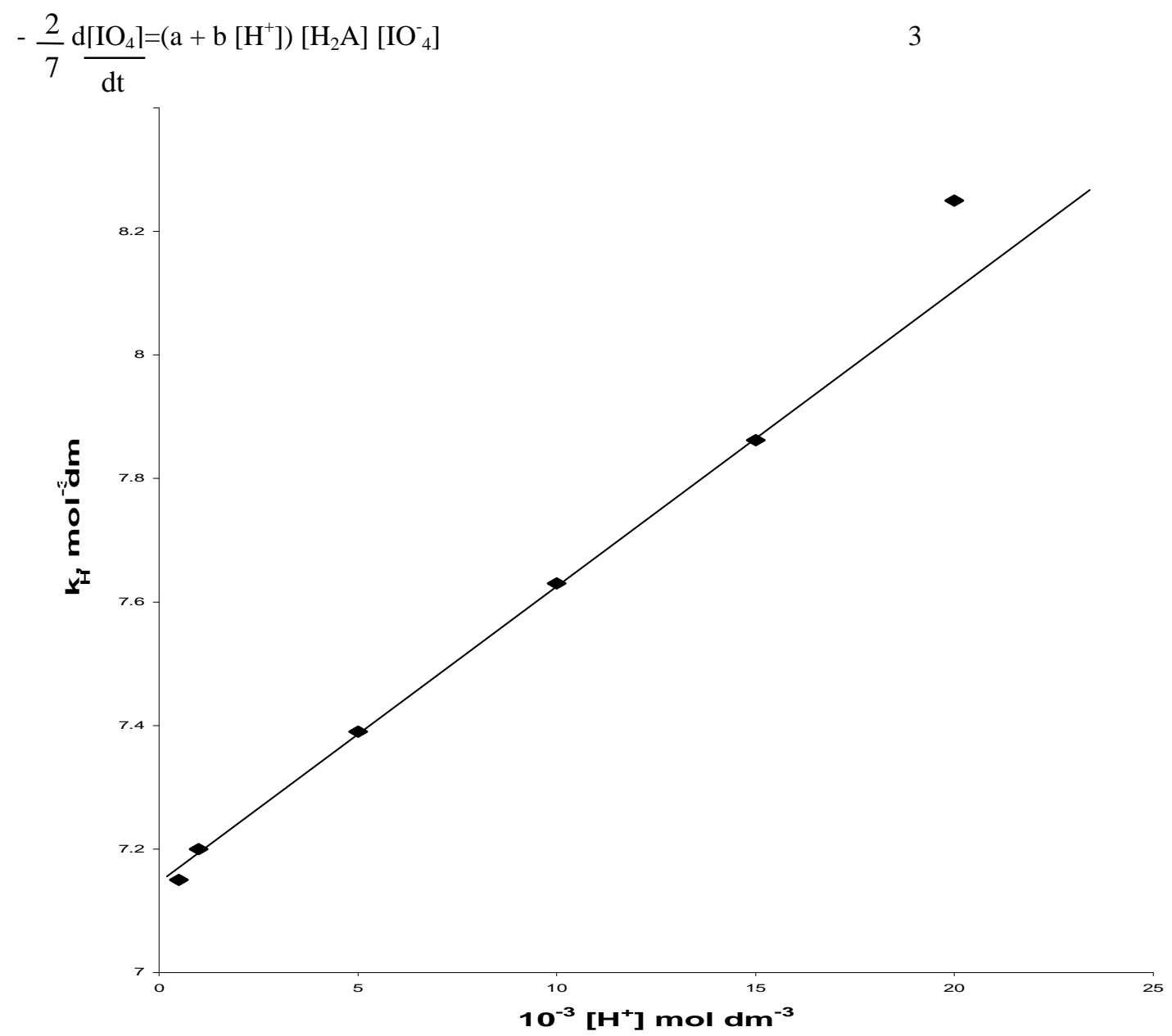

Figure 3. Dependence of the observed rate constants $\left(\mathrm{k}_{\mathrm{H}}\right)$ on hydrogen ion concentration $\left[\mathrm{H}^{+}\right]$for oxidation of $\mathrm{H}_{2} \mathrm{~A}_{\text {by } \mathrm{IO}_{4}^{-}}^{-} . \quad\left[\mathrm{H}_{2} \mathrm{~A}\right]=1 \times 10^{-3} \mathrm{~mol} \mathrm{dm}{ }^{-3}, \mathrm{~T}=$ $29 \pm 1^{\circ} \mathrm{C},\left[\mathrm{IO}_{4}^{-}\right]=1 \times 10^{-3} \mathrm{~mol} \mathrm{dm}{ }^{-3}, \lambda_{\max }=580 \mathrm{~nm}$

\subsection{Effect of Ionic Strength}

The ionic strength was varied from $0.4-2.0 \mathrm{~mol} \mathrm{dm}^{-3}(\mathrm{NaCl})$ at constant reactant concentration and hydrogen ion concentration. The rate of reaction was found to increase with increase in ionic strength. A plot of $\log \mathrm{k}_{2}$ versus $\sqrt{\mathbf{I}}$ gave a linear graph with a slope of 1.15 (Figure 4) showing a positive salt effect. This suggests absence of formation of intermediate complex in the reaction, thus supporting the occurrence of outer sphere mechanism (Benson,1968 and 
Babatunde 2008).

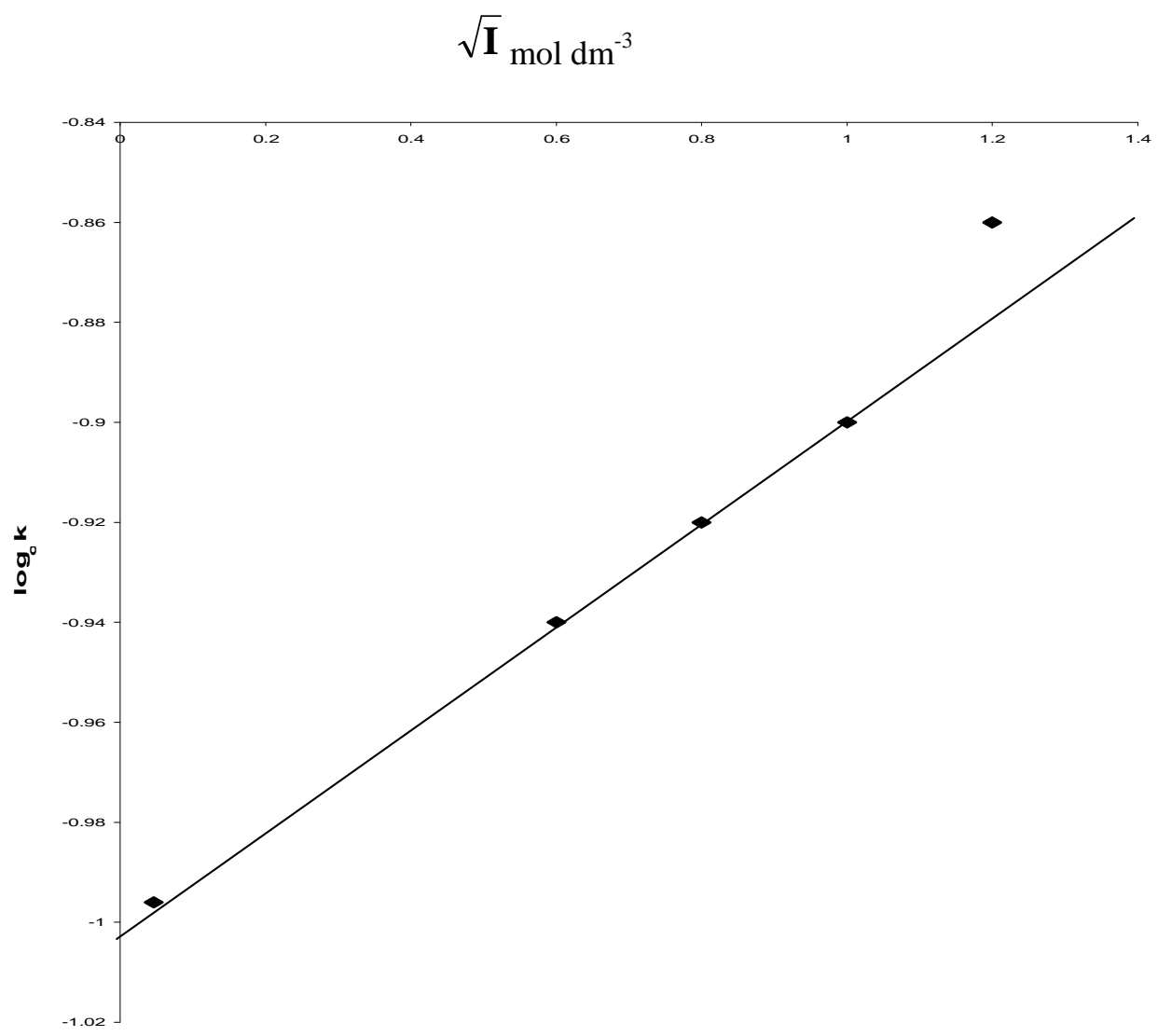

Figure 4. Dependence of the observed rate constants $\left(\log k_{0}\right)$ on the Ionic strength $(\sqrt{\mathbf{I}})$ for oxidation of $\mathrm{H}_{2} \mathrm{~A}$ by $\mathrm{IO}_{4}^{-} \cdot\left[\mathrm{H}_{2} \mathrm{~A}\right]=1 \times 10^{-3} \mathrm{~mol} \mathrm{dm}{ }^{-3}, \mathrm{~T}=29 \pm 1^{\circ} \mathrm{C},\left[\mathrm{IO}_{4}^{-}\right]=1 \times 10^{-3} \mathrm{~mol} \mathrm{dm}^{-3}$,

$$
\lambda_{\max }=580 \mathrm{~nm}
$$

\subsection{Effect of Added Anion Species}

The results obtained from the effect of added anions $\left(\mathrm{NO}_{3}{ }^{-} \mathrm{CH}_{3} \mathrm{COO}^{-}, \mathrm{SO}_{4}{ }^{2-}\right)$ on the rate of the reaction were presented in Table 3. The added ions led to increase in the rate of reaction. This suggests outer sphere mechanism.

Table 3. Summary of the effect of added ion $\mathrm{X}$ on the rate of oxidation of $\mathrm{H}_{2} \mathrm{~A}$ by $\mathrm{IO}_{4}{ }^{-}$.

$\left[\mathrm{H}_{2} \mathrm{~A}\right]=1 \times 10^{-3} \mathrm{~mol} \mathrm{dm}^{-3}, \mathrm{~T}=29 \pm 1^{\circ} \mathrm{C},\left[\mathrm{IO}_{4}{ }^{-}\right]=1 \times 10^{-3} \mathrm{~mol} \mathrm{dm}{ }^{-3}, \lambda_{\max }=580 \mathrm{~nm}$

\begin{tabular}{|l|l|l|l|}
\hline $\mathrm{X}$ & $10^{3}[\mathrm{X}] \mathrm{mol} \mathrm{dm}^{-3}$ & $10_{2} \mathrm{k}_{\mathrm{o}} \mathrm{s}^{-1}$ & $10^{-1} \mathrm{k}_{2} \mathrm{dm}_{3} \mathrm{~mol}^{-1} \mathrm{~s}^{-1}$ \\
\hline & 0.4 & 2.89 & 7.23 \\
$\mathrm{NO}_{3}{ }^{-}$ & 0.6 & 4.35 & 7.25 \\
& 0.8 & 5.83 & 7.29 \\
& 1.0 & 7.32 & 7.32 \\
\hline
\end{tabular}




\begin{tabular}{|l|l|l|l|}
\hline & 0.4 & 2.87 & 7.17 \\
$\mathrm{CH}_{3} \mathrm{COO}^{-}$ & 0.6 & 4.34 & 7.27 \\
& 0.8 & 5.88 & 7.35 \\
& 1.0 & 7.46 & 7.46 \\
\hline & & & \\
$\mathrm{SO}_{4}{ }^{2-}$ & 0.4 & 2.84 & 7.10 \\
& 0.6 & 4.30 & 7.16 \\
& 0.8 & 5.80 & 7.25 \\
& 1.0 & 7.38 & 7.38 \\
\hline
\end{tabular}

\subsection{Test for Intermediate Complex}

Michael's Metens plot of $1 / \mathbf{k}_{\mathbf{0}}$ versus $\frac{\mathbf{1}}{\left[\mathbf{H}_{\mathbf{2}} \mathbf{A}\right]}$ were linear without any intercept.(Table 4,

Figure 5) This suggests absence of the intermediate complex formation prior to the electron transfer in the reactions. Similar observation was reported for the oxidation of $\mathrm{H}_{2} \mathrm{~A}$ with various reductants (Iyun et al.,2005, Babatunde 2008,McCartney and Sutin, 1983).

Table 4. Data for Micheal'sMetens Plot.

\begin{tabular}{|r|r|r|r|r|r|}
\hline $10^{2}\left[\mathrm{H}_{2} \mathrm{~A}\right]$ & $10^{2} \mathrm{ko}$ & $\log \mathrm{ko}$ & $\log \left[\mathrm{H}_{2} \mathrm{~A}\right]$ & $1 / \mathrm{ko}$ & $1 /\left[\mathrm{H}_{2} \mathrm{~A}\right]$ \\
\hline 10 & 7.1 & -1.15 & -1.00 & 14.08 & 10.00 \\
\hline 12 & 8.7 & -1.06 & -0.92 & 11.49 & 8.33 \\
\hline 14 & 9.9 & -1.00 & -0.85 & 10.10 & 7.14 \\
\hline 16 & 11.5 & -0.94 & -0.80 & 8.70 & 6.25 \\
\hline 18 & 12.8 & -0.89 & -0.75 & 7.81 & 5.56 \\
\hline 20 & 14.3 & -0.85 & -0.70 & 6.99 & 5.00 \\
\hline 22 & 15.8 & -0.80 & -0.66 & 6.33 & 4.55 \\
\hline 24 & 17.2 & -0.77 & -0.62 & 5.81 & 4.17 \\
\hline 26 & 18.7 & -0.73 & -0.59 & 5.35 & 3.85 \\
\hline 28 & 20.1 & -0.70 & -0.55 & 4.98 & 3.57 \\
\hline 30 & 21.5 & -0.66 & -0.52 & 4.65 & 3.33 \\
\hline
\end{tabular}




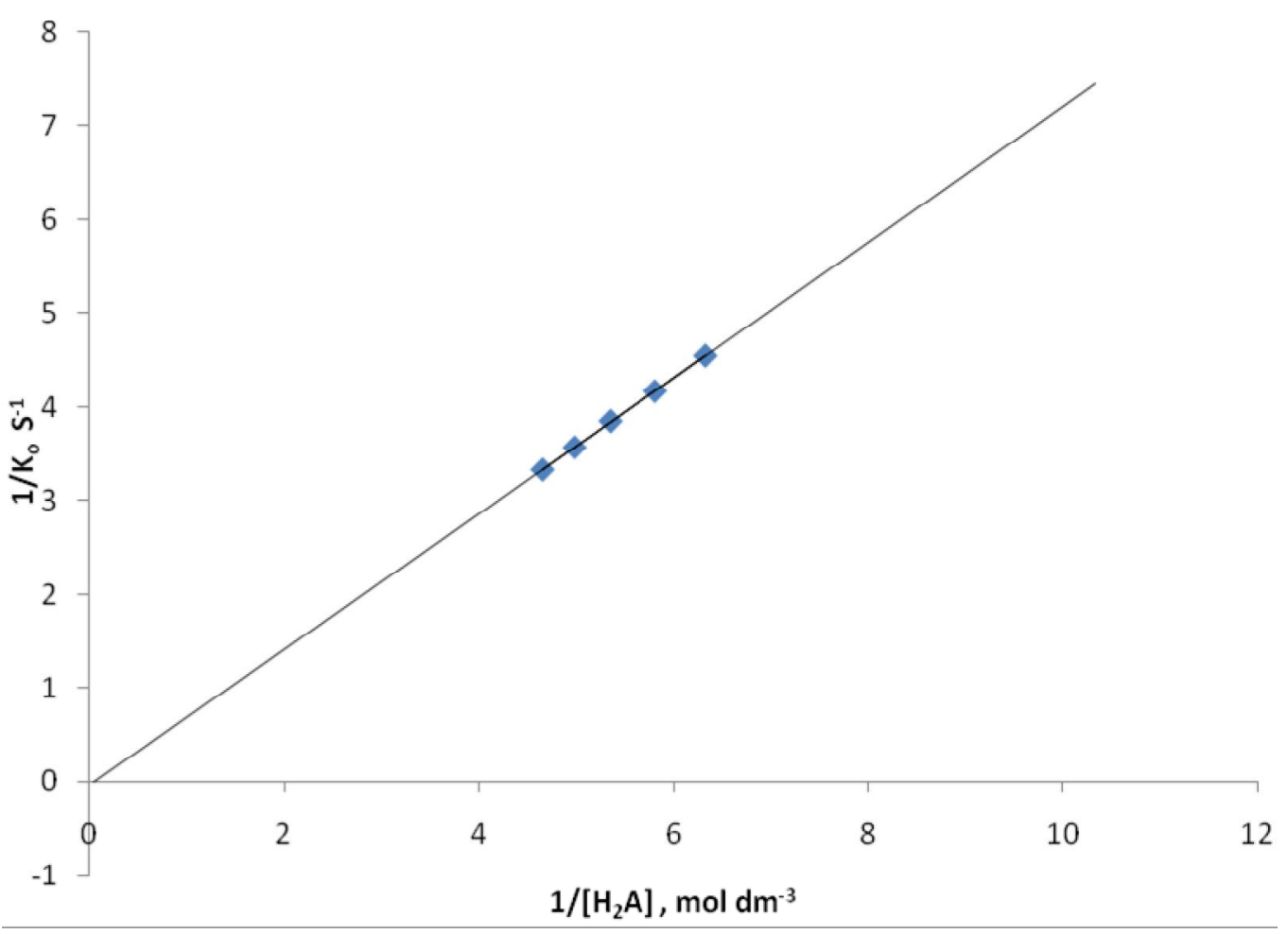

Figure 5. Graph of $1 / \mathrm{k}_{\mathrm{o}}$ against $1 /\left[\mathrm{H}_{2} \mathrm{~A}\right]$ for Micheal'sMenten's plot

\subsection{Test for Free Radical}

No gel formation was observed on addition of a solution of acrylamide to partially reacted mixture of $\mathrm{H}_{2} \mathrm{~A} \& \mathrm{IO}_{4}$ in the presence of large excess of methanol thus confirming absence of free radicals in the reaction mechanism (Przystas and Sutin 1973). This suggests the contribution of outer sphere mechanism (Bamford and Tipper 1967).

\subsection{Proposed Mechanism}

Based on the experimental results of this investigation, the following mechanistic steps are consistent with the rate law postulated for the oxidation of $\mathrm{H}_{2} \mathrm{~A}$ by $\mathrm{IO}_{4}{ }^{-}$.

$$
\begin{aligned}
& \mathrm{H}_{2} \mathrm{~A}+\mathrm{H}^{+} \underset{\text { fast }}{\stackrel{\mathrm{K}}{\rightleftharpoons}} \mathrm{H}_{3} \mathrm{~A}^{+} \quad \text {............ } \\
& \mathrm{H}_{2} \mathrm{~A}+\mathrm{IO}_{4}^{-} \underset{\mathrm{k}_{2}}{\stackrel{\text { slow }}{\longrightarrow}} \mathrm{IO}_{3}^{-}+\mathrm{H}_{2} \mathrm{O}+\mathrm{A} \\
& \mathrm{H}_{3} \mathrm{~A}+\mathrm{IO}_{4}^{-} \underset{\text { slow }}{\stackrel{\mathrm{k}_{3}}{\longrightarrow}} \mathrm{HIO}_{3}+\mathrm{H}_{2} \mathrm{O}+\mathrm{A} \\
& \mathrm{IO}_{3}{ }^{-}+3 \mathrm{H}_{2} \mathrm{~A} \underset{\text { fast }}{\longrightarrow} \mathrm{I}^{-}+3 \mathrm{H}_{2} \mathrm{O}+3 \mathrm{~A} \\
& \mathrm{HIO}_{3}+2 \mathrm{H}_{2} \mathrm{~A} \underset{\text { fast }}{\longrightarrow} \mathrm{HOI}+2 \mathrm{H}_{2} \mathrm{O}+2 \mathrm{~A} \quad \ldots \ldots \ldots \ldots . .8 \\
& \mathrm{HOI}+\mathrm{H}^{+}+\mathrm{I}^{-} \longrightarrow \mathrm{I}_{2}+\mathrm{H}_{2} \mathrm{O}
\end{aligned}
$$

From equation 4 
$\mathrm{K}_{1}=\underline{\mathrm{H}_{3}} \underline{\left.\mathrm{A}^{+}\right]}$

$\left[\mathrm{H}_{2} \mathrm{~A}\right]\left[\mathrm{H}^{+}\right]$

Using equation 5 and 6 as the rate determining steps

Rate $=\mathrm{k}_{2}\left[\mathrm{H}_{2} \mathrm{~A}\right]\left[\mathrm{IO}_{4}^{-}\right]+\mathrm{k}_{3}\left[\mathrm{H}_{3} \mathrm{~A}^{+}\right]\left[\mathrm{IO}_{4}^{-}\right]$

Substitute equation 10 in equation 11

Rate $=\mathrm{k}_{2}\left[\mathrm{H}_{2} \mathrm{~A}\right]\left[\mathrm{IO}_{4}^{-}\right]+\mathrm{k}_{3}\left[\mathrm{H}^{+}\right]\left[\mathrm{H}_{2} \mathrm{~A}^{+}\right]\left[\mathrm{IO}_{4}^{-}\right]$

Rate $=\mathrm{k}_{2}+\mathrm{k}_{3} \mathrm{~K}_{1}\left[\mathrm{H}^{+}\right]\left[\mathrm{H}_{2} \mathrm{~A}\right]\left[\mathrm{IO}_{4}^{-}\right]$

Equation 13 is analogous to equation 3

Where $\mathrm{k}_{2}=\mathrm{a}$ and $\mathrm{k}_{3} \mathrm{~K}_{1}=\mathrm{b}$

The above reaction steps point to an outer sphere electron transfer process.

\section{Conclusion}

In conclusion, this reaction indicates a second order rate law and is dependent on hydrogen ion concentration. Also scanning of the reaction mixture did not show any shift in $\lambda_{\max }$ pointing to the absence of formation of intermediate complex and absence of free radical formation during the reaction. All these points above are in support of the outer sphere mechanism. Therefore, the reaction occurs probably by outer sphere mechanism.

\section{References}

Akhtar, M. J., \& Haim, A, (1988). Kinectics and mechanism of the reaction of mononuclear and binuclear Ruthanium (II) ammine complexes with Ascorbic acid. Inorganic Chem., 27. 1608 .

Babatunde, O. A., (2008). A study of the kinetics and mechanism of oxidation L-ascorbic acid by permanganate ion in acidic medium. World J. Chem., 3, 27 -31.

Babatunde, O. A., (2009). Kinetics and mechanism of reduction of parafuchsin by nitrite ions in aqueous acid medium. World J. Chem., 4, 39-44.

Bamford, C. H., \& C. P. H. Tipper, (1967).Comprehensive Chemical Kinetics. Elsevier, New York, Pages: 2786

Benson, D., (1968). Mechanism of Inorganic Reactions in Solution. McGraw Hill, London, $153-154$

Birck, G. G. \& K. Parket, (1974). Vitamin C Recent Aspects of its Physiological and Technological Importance. Applied Science, London, 10-15.

Cruetz, C., (1981). The complexeties of Ascorbate as a reducing agent. Inorg. Chem., 20, 4449-4452. http://dx.doi.org/10.1021/ic50226a088

Ghosh, S. K. \& E. S. Goud, (1989). Electron Transfer 98: Copper (II) and Vanadium (IV) catalysis of the reduction of peroxide-bound chromium(IV) with ascorbic acid. Inorg. Chem., 28, 1948-1951. http://dx.doi.org/10.1021/ic00309a035 
Hassan, M. Y., \& Ahmed, F. (1995). Role of anionic micelles in the oxidation of DL-Leucine by acid permanganese. A Kinetic Study.Communi, 18,128.

Hamza S A, J. F Iyun, \& S. O Idris. (2012). Kinetics approach to the Mechanism of the reduction of toluidine blue by Ascorbic acid.Scholars Research Library. Der pharmachemical, $4(1), 1-9$.

Iyun, J. F., A. O. Peters \& O. A. Babatunde, (2005). Kinetics of the reduction of dioxotetrakis(1,10 phenanthroline)di manganese (III,IV) perchlorate by L-Ascorbic acid in aqueous acid solution. J. Chem. Soc. Nig., 2, 114-118.

Iyun, J. F., Ayoko G. A., \& Lawal H. A. (1995). Kinetics and Mechanism of the reduction of Diaquatetrakis 2,2 (bipyridine)- $\mu$-oxodiruthenium (III) by Ascorbic acid. Transition Metal Chemistry. 20, 30-33. http://dx.doi.org/10.1007/BF00135398

Lawrence, G. S., \& K. J. Ellis, (1972). The Detection of a complex intermediate in the oxidation of Ascorbic acid and Ferric ions. J. Chem. Soc. Dalton Trans., 15, 1667-1670. http://dx.doi.org/10.1039/dt9720001667

Levine M., Sc. Rumsey, Y. wang, J. B Park, \& R Daruwala, (2000). Vitamin C “ inStipanuk MH. Biochemical and Physiological aspects of human nutrition. Philadelphia W.B Saunders, 541-67.

McCartney, D. H., \& N. Sutin, (1983). The oxidation of ascorbic acid by Tris(2,2-bipyridine) compiexes of Osmium (III) and Nickel (III) in aqueous media .Applications of the Marcus cross-relations. Inorg.Chim. Acta, 74, 221-225. http://dx.doi.org/10.1016/S0020-1693 (00)81430-9

Mushroom, S. P., M. C. Agrawal, R. M. Mehrota \& R. Sanetic, (1974). Kinetics and mechanism of reduction of silve $\mathrm{r}$ (I) by ascorbic acid. J. Chem. Soc. Dalton Trans., 14, 1460-1462. http://dx.doi.org/10.1039/dt9740001460

Przystas T. J., \& Sutin. N. (1973). Kinetics studies of anion assisted outersphere electron transfet reaction. J. Amer.Chem Soc., 95, 554. http://dx.doi.org/10.1021/ja00798a020

Swapan Chaudhuri, Subrata Mukhopadhyay \& Rupendrnath Banerjee. (1995). Solution Equilibria and Redox Reactivities of a Di oxo-bridged Manganese Complex. J. Chem. Soc. Dalton Trans, 621-525.

\section{Copyright Disclaimer}

Copyright reserved by the author(s).

This article is an open-access article distributed under the terms and conditions of the Creative Commons Attribution license (http://creativecommons.org/licenses/by/3.0/). 